\title{
Granulomatous pigmented purpuric dermatosis
}

\author{
Sónia Raquel Mendes, Ana Rita Gameiro, José Carlos Cardoso, José Pedro Reis
}

Dermatology Department Coimbra University Hospital, Coimbra, Portugal

\section{Correspondence to}

Dr Sónia Raquel Mendes; soniaraquel23@gmail.com

Accepted 5 January 2021
D) Check for updates

C) BMJ Publishing Group Limited 2021. No commercial re-use. See rights and permissions. Published by BMJ.

To cite: Mendes SR Gameiro AR, Cardoso JC, et al. BMJ Case Rep 2021;14:e240052 doi:10.1136/bcr-2020240052

\section{DESCRIPTION}

A 61-year-old Caucasian female patient presented with erythematous-violaceous purpuric macules and punctiform papules, involving the dorsum of the feet and the legs, evolving for 1 month. The lesions were mildly pruritic and non-blanchable (figure 1). Her medical history includes hyperlipidaemia, high blood pressure, varicose veins and type 2 diabetes. No new medications were given in the past 11 months.

We performed a cutaneous biopsy on the right leg that revealed atrophy of the epidermis, vasodilation in the superficial dermis and a non-necrotising granulomatous infiltrate consisting of relatively well-circumscribed granulomas with a peripheral lymphocytic crown. The infiltrate was associated with marked haemosiderin deposition in the adjacent dermis, confirmed by Perls stain (figure 2), but no vasculitis features were observed. These findings are consistent with granulomatous pigmented purpuric dermatoses (PPDs). Treatment with topical corticosteroids during 2 months and emollients during 1 year resulted in moderate improvement.

Granulomatous PPD is a rare subtype of PPD that is typically seen in women of Far East Asian descent on the distal lower extremities and feet. ${ }^{1-3}$ Saito and Matsuoka reported granulomatous PPD for the first time in $1996 .{ }^{4}$ The condition is usually distinguished from other types of PPDs by the detection of a granulomatous infiltrate on histopathology in addition to the other features of PPD. ${ }^{134}$ This variant has been associated with hyperlipidaemia, although this association is unclear and requires further investigation. ${ }^{2}$ Other frequent findings described are arterial hypertension and diabetes mellitus. ${ }^{25}$ The differential diagnosis of PPDs includes cutaneous vasculitis,

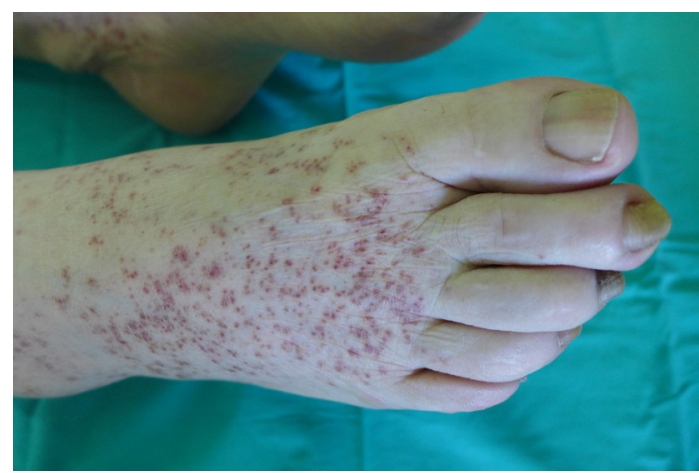

Figure 1 Erythematous-violaceous purpuric macules and punctiform papules, non-blanchable, located in the anterolateral aspect of the legs and the dorsum of the feet, more exuberant to the right side.

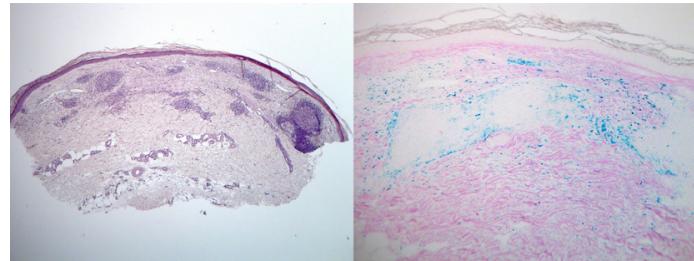

Figure 2 Non-necrotising granulomatous infiltrate in the superficial and middle dermis with a predominantly perivascular distribution (H\&E 25x), Perls stain showing haemosiderin deposition (100x).

stasis dermatitis, traumatic purpura and mycosis fungoides. ${ }^{1}$ Treatment is not always necessary and is generally considered for patients with associated symptoms or because the cosmetic appearance of the skin lesions. ${ }^{2}$

\section{Learning points}

- Granulomatous pigmented purpuric dermatosis (PPD) is a rare subtype of PPD distinguished by the detection of a granulomatous infiltrate on histopathology in addition to the other features of PPD.

- Granulomatous PPD is a benign condition that does not typically require treatment.

Contributors SRM (first author): acquisition and analysis of data, planning, conducting, conception and design of the article, as well as revision and final approval. ARG: acquisition of data, revision and final approval. JCC: acquisition of data, revision and final approval. JPR: acquisition of data and final approval.

Funding The authors have not declared a specific grant for this research from any funding agency in the public, commercial or not-for-profit sectors

Competing interests None declared.

Patient consent for publication Obtained.

Provenance and peer review Not commissioned; externally peer reviewed.

\section{REFERENCES}

1 Battle LR, Shalin SC, Gao L. Granulomatous pigmented purpuric dermatosis. Clin Exp Dermatol 2015;40:387-90.

2 Hanson C, Fischer R, Fraga G, et al. Granulomatous pigmented purpuric dermatosis: an unusual variant associated with hyperlipidemia. Dermatol Online J 2014;21. [Epub ahead of print: 16 Nov 2014].

3 Wong WR, Kuo TT, Chen MJ, et al. Granulomatous variant of chronic pigmented purpuric dermatosis: report of two cases. $\mathrm{Br}$ I Dermatol 2001;145:162-4.

4 Saito R, Matsuoka Y. Granulomatous pigmented purpuric dermatosis. J Dermatol 1996;23:551-5.

5 Carvajal D, Quiroz C, Morales C, et al. Granulomatous pigmented purpuric dermatosis: report of a Latin-American case with blaschkoid distribution. An Bras Dermatol 2019;94:582-5. 
Copyright 2021 BMJ Publishing Group. All rights reserved. For permission to reuse any of this content visit https://www.bmj.com/company/products-services/rights-and-licensing/permissions/

BMJ Case Report Fellows may re-use this article for personal use and teaching without any further permission.

Become a Fellow of BMJ Case Reports today and you can:

- Submit as many cases as you like

Enjoy fast sympathetic peer review and rapid publication of accepted articles

Access all the published articles

Re-use any of the published material for personal use and teaching without further permission

Customer Service

If you have any further queries about your subscription, please contact our customer services team on +44 (0) 2071111105 or via email at support@bmj.com.

Visit casereports.bmj.com for more articles like this and to become a Fellow 